\title{
Targeting metabotropic glutamate receptors in the treatment of epilepsy: rationale and current status
}

\section{Roberta Celli, Ines Santolini, Gilles Van Luijtelaar, Richard T Ngomba, Valeria Bruno \& Ferdinando Nicoletti}

To cite this article: Roberta Celli, Ines Santolini, Gilles Van Luijtelaar, Richard T Ngomba, Valeria Bruno \& Ferdinando Nicoletti (2019) Targeting metabotropic glutamate receptors in the treatment of epilepsy: rationale and current status, Expert Opinion on Therapeutic Targets, 23:4, 341-351, DOI: 10.1080/14728222.2019.1586885

To link to this article: https://doi.org/10.1080/14728222.2019.1586885

Accepted author version posted online: 25

Feb 2019.

Published online: 21 Mar 2019.

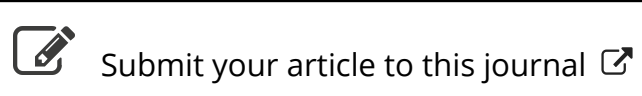

Џ Article views: 106

View Crossmark data \lceil 


\title{
Targeting metabotropic glutamate receptors in the treatment of epilepsy: rationale and current status
}

\author{
Roberta Cellia, Ines Santolinia, Gilles Van Luijtelaar ${ }^{\mathrm{b}}$, Richard T Ngombac, Valeria Bruno ${ }^{\mathrm{a}, \mathrm{d}}$ and Ferdinando Nicolettia,d
}

aIRCCS NEUROMED, Pozzilli, Italy; bDonders Centre for Cognition, Radboud University, Nijmegen, The Netherlands; 'School of Pharmacy, University of Lincoln, Lincoln, UK; ${ }^{d}$ Departments of Physiology and Pharmacology, University Sapienza, Rome, Italy

\begin{abstract}
Introduction: Several drugs targeting the GABAergic system are used in the treatment of epilepsy, but only one drug targeting glutamate receptors is on the market. This is surprising because an imbalance between excitatory and inhibitory neurotransmission lies at the core of the pathophysiology of epilepsy. One possible explanation is that drug development has been directed towards the synthesis of molecules that inhibit the activity of ionotropic glutamate receptors. These receptors mediate fast excitatory synaptic transmission in the central nervous system (CNS) and their blockade may cause severe adverse effects such as sedation, cognitive impairment, and psychotomimetic effects. Metabotropic glutamate (mGlu) receptors are more promising drug targets because these receptors modulate synaptic transmission rather than mediate it.

Areas covered: We review the current evidence that links mGlu receptor subtypes to the pathophysiology and experimental treatment of convulsive and absence seizures.

Expert opinion: While $\mathrm{mGlu}_{5}$ receptor negative allosteric modulators have the potential to be protective against convulsive seizures and hyperactivity-induced neurodegeneration, drugs that enhance $\mathrm{mGlu}_{5}$ and $\mathrm{mGlu}_{7}$ receptor function may have beneficial effects in the treatment of absence epilepsy. Evidence related to the other mGlu receptor subtypes is more fragmentary; further investigations are required for an improved understanding of their role in the generation and propagation of seizures.
\end{abstract}

ARTICLE HISTORY

Received 10 October 2018

Accepted 21 February 2019

\section{KEYWORDS}

Metabotropic glutamate receptors; epilepsy; convulsive seizures; absence seizures

\section{Introduction}

An imbalance between excitatory and inhibitory neurotransmission is one of the key mechanisms in the development of epileptic seizures, and this provides the rationale for the use of drugs that enhance inhibition by increasing extracellular GABA concentration (e.g., valproate, tiagabine, vigabatrine) or activating $\mathrm{GABA}_{\mathrm{A}}$ receptors (e.g., benzodiazepines). On the other side of the coin, only one drug that reduces excitation by specifically targeting glutamate receptors, the a-amino3-hydroxy-5-methyl-4-isoxazolepropionic acid (AMPA) receptor antagonist perampanel, is currently used in the treatment of focal epilepsy [1]. This is quite surprising if one considers the higher density of excitatory pyramidal neurons with respect to inhibitory GABAergic interneurons in the cerebral cortex and hippocampus (e.g., about $85 \%$ vs. $15 \%$ of the overall neuronal population in particular regions of the cerebral cortex, respectively). Glutamate receptors are divided into two major superfamilies: (i) ionotropic (iGlu) receptors, which form membrane cation channels; and (ii) metabotropic (mGlu) receptors, which are coupled to effectors via $\mathrm{G}$ proteins. iGlu receptors include AMPA, NMDA (N-methylD-aspartate), and kainate receptors, and they are all formed by the heteromeric assembly of four subunits, which determine the ion selectivity and kinetic properties of the ion channels. AMPA-gated ion channels are selectively permeable to $\mathrm{Na}^{+}$ions at most of the excitatory synapses because of the presence of the GluA2 subunit, which prevents $\mathrm{Ca}^{2+}$ influx through the channel. In contrast, NMDA receptors are highly permeable to $\mathrm{Ca}^{2+}$ ions, but they are inhibited by physiological concentrations of extracellular $\mathrm{Mg}^{2+}$ [2]. Membrane depolarization removes the $\mathrm{Mg}^{2+}$ blockade of the NMDA-gated ion channel, thereby allowing a large influx of extracellular $\mathrm{Ca}^{2+}$ in neurons when NMDA receptors are activated by glutamate in the presence of the co-agonist, glycine [2,3]. Activation of NMDA receptors is a key event in the induction of activitydependent synaptic plasticity (i.e., long-term potentiation and long-term depression of excitatory synaptic transmission) [4], and is also involved in the induction of electrical kindling $[5,6]$, which is a model of epileptogenesis, i.e. gradual process by which a normal brain is biased towards the generation of epilepsy. One of the reasons why drugs that primarily block iGlu receptors are not currently used in the treatment of epilepsy (with the notable exception of perampanel) is that iGlu receptors mediate fast excitatory synaptic transmission, and chronic pharmacological blockade of these receptors may cause a sustained depression of synaptic transmission and an impairment of activity-dependent synaptic plasticity resulting in cognitive dysfunction. In addition, pharmacological inhibition of NMDA receptors may produce psychotomimetic effects, as typically observed with the slow NMDA channel blockers, ketamine and phencyclidine [7]. 
Article Highlights

- There is a need for new drugs for the treatment of epilepsy.

- Metabotropic glutamate receptors are candidate drug targets for the treatment of epilepsy because they modulate excitatory and inhibitory neurotransmission.

- Positive allosteric modulators of $\mathrm{mGlu}_{5}$ and $\mathrm{mGlu}_{7}$ receptors hold promise for the treatment of epileptic syndromes characterized by absence seizures.

- Drugs that activate $\mathrm{mGlu}_{2}$ receptors or inhibit $\mathrm{mGlu}_{5}$ receptors are potentially effective in the treatment of convulsive seizures.

- The study of mGlu receptors in the process of epileptogenesis is in its infancy.

This box summarizes the key points contained in the article.

As opposed to iGlu receptors, mGlu receptors do not mediate but rather 'modulate' synaptic transmission acting at different levels of the tripartite synapse formed by the junction of axon terminals, dendritic spines, and astrocytes $[8,9]$. This shifts attention to mGlu receptors as candidate drug targets in the experimental treatment of epilepsy.

\section{Metabotropic glutamate receptors and epilepsy}

mGlu receptors are $\mathrm{G}$ protein-coupled receptors activated by glutamate and are involved in the modulation of synaptic transmission. They are mainly expressed in the central nervous system (CNS) and consist of eight subtypes divided into three groups based on amino acid sequence, pharmacological properties, and signaling transduction pathways [10]. Specifically, group I comprises $\mathrm{mGlu}_{1}$ and $\mathrm{mGlu}_{5}$ receptors, which are expressed primarily at postsynaptic sites and are coupled to $\mathrm{G}_{\mathrm{q}} / \mathrm{G}_{11}$ proteins associated with stimulation of the phospholipase $C$ pathway. Their activation stimulates the hydrolysis of phosphatidylinositol-4,5-bisphosphate, with the formation of inositol-1,4,5-trisphosphate ( $\left(\operatorname{ns}_{3}\right.$ ) and diacylglycerol (DAG). Ins $\mathrm{P}_{3}$ and DAG enhance intracellular $\mathrm{Ca}^{2+}$ release and activate protein kinase $C$, respectively. Group II comprises $\mathrm{mGlu}_{2}$ and $\mathrm{mGlu}_{3}$ receptors coupled to $\mathrm{G}_{\mathrm{i}} / \mathrm{G}_{\mathrm{o}}$ proteins, which transduce the signal via inhibition of adenylyl cyclase and the modulation of $\mathrm{Ca}^{2+}$ and $\mathrm{K}^{+}$channels [11]. $\mathrm{mGlu}_{2}$ receptors are mainly localized in nerve endings, where they negatively modulate neurotransmitter release. $\mathrm{mGlu}_{3}$ receptors share the same presynaptic localization, but, in addition, are also found in postsynaptic elements, where they functionally interact with $\mathrm{mGlu}_{5}$ receptors [12]. $\mathrm{mGlu}_{3}$ receptors are also expressed by astrocytes and microglia, where they regulate the production of neurotrophic factors and cytokines [9]. Finally, group III comprises mGlu $\mathrm{mGlu}_{6}, \mathrm{mGlu}_{7}$, and $\mathrm{mGlu}_{8}$ receptors, which are coupled to $\mathrm{Gi} / \mathrm{o}$ proteins, and are expressed in presynaptic terminals where they inhibit neurotransmitter release [13].

mGlu receptors form constitutive dimers composed of two subunits linked by a disulfide bridge [14]. Each subunit contains an extracellular orthosteric glutamate binding site (Venus Flytrap domain, VFTD [15];), and allosteric binding sites located within the seven transmembrane domains (7TMD) [16].

mGlu receptors are proposed as potential therapeutic targets for the treatment of neurologic and psychiatric disorders and, thus, several compounds have been developed as subtype-selective mGlu receptor ligands $[9,17]$.

Almost $30 \%$ of epileptic patients are resistant to current pharmacological treatments [18], which include (i) inhibitors of voltage-sensitive sodium channels, such as phenytoin, carbamazepine, oxcarbazepine, lamotrigine, and lacosamide; (ii) GABA-mimetic drugs, such as benzodiazepines, barbiturates, tiagabine, and vigabatrine; (iii) drugs interacting with the SV2A synaptic vesicle protein, such as levetiracetam and brivaracetam; (iv) inhibitors of T-type voltage-sensitive calcium channels, such as ethosuximide; (v) inhibitors of the $\boldsymbol{I}_{2} \mathbf{I}$ subunit of voltage-sensitive calcium channels, such as gabapentin and pregabalin; and (vi) drugs showing pleiotropic mechanisms, such as valproate, topiramate, zonisamide, and felbamate. In addition, some conventional antiepileptic drugs such as phenytoin and carbamazepine have a narrow therapeutic margin and require therapeutic drug monitoring [19]. Thus, new antiepileptic drugs to ameliorate current therapies and to treat the drug-resistant form of epilepsies are badly needed [20]. Owing to their modulatory function, mGlu receptors have been implicated in the control of epileptic seizures [21], and in mechanisms of epileptogenesis and hyperactivity-induced neuronal damage $[22,23]$.

Several selective agonists and antagonists of individual mGlu receptor subtypes have been developed as valuable tools to probe the role of mGlu receptors in physiology and pathology, and some of these compounds have been, or are currently being evaluated in clinical studies [24].

mGlu receptors could play a role in ictogenesis by increasing or decreasing the effects caused by an excessive activation of iGlu receptors [25], and some subtype-selective ligands might improve the therapeutic effect of antiepileptic drugs by modulating either excitatory or inhibitory neurotransmission [26]. The role of mGlu receptors in the pathophysiology and treatment of epilepsy has been the subject of numerous review articles in the last two decades [27-33].

The recent development of selective ligands of individual mGlu receptor subtypes and their use in experimental animal models of convulsive and absence seizures gave us the impetus to further discuss the topic and comment on the potential use of these compounds in the treatment of epilepsy.

\subsection{Group I mGlu receptors and convulsive seizures}

A large body of evidence has shown that $\mathrm{mGlu}_{5}$ receptors are up-regulated in tissue specimens from patients suffering from temporal lobe epilepsy, as well as in the rodent hippocampus after induction of limbic seizures. Eleonora Aronica and her Associates were the first to show an increased expression of $\mathrm{mGlu}_{5}$ (and $\mathrm{mGlu}_{3}$ ) receptors in hippocampal astrocytes in a rat model of temporal lobe epilepsy [34]. These findings laid the groundwork for the study of mGlu receptor expression in the hippocampus of patients suffering from mesial temporal lobe epilepsy (TLE). Tang et al. [35] found increases in $\mathrm{mGlu}_{1}$ and $\mathrm{mGlu}_{5}$ receptor immunoreactivity in the dentate gyrus and CA1 region of TLE patients. While $\mathrm{mGlu}_{1}$ immunoreactivity was exclusively localized in postsynaptic elements, $\mathrm{mGlu}_{5}$ receptor immunoreactivity was detected in both pre- and postsynaptic elements, as well as 
in astrocytes. Similarly, Blümcke et al. [36] observed an increased expression of $\mathrm{mGlu}_{1}$ receptors in the dentate gyrus of epileptic human and rat hippocampus. The upregulation of $\mathrm{mGlu}_{5}$ receptors was confirmed in more recent studies examining hippocampal tissue specimens of drugresistant patients with TLE. The increase in $\mathrm{mGlu}_{5}$ receptor expression was more prominent in patients with Ammon's horn sclerosis, where it correlated with mossy fiber sprouting $[37,38]$. One possible interpretation of these data is that the increased expression of $\mathrm{mGlu}_{5}$ receptors contributes to mechanisms of maladaptive neuronal plasticity that sustain seizures associated with TLE or, alternatively, might represent a defensive mechanism of postsynaptic adaptation that tries to control over-excitation [38].

Pharmacological blockade of either $\mathrm{mGlu}_{1}$ or $\mathrm{mGlu}_{5}$ receptors is protective in models of convulsive seizures, suggesting that the overall function of group-I mGlu receptors is to increase excitability in neuronal circuits involved in the generation of convulsive seizures. Brian Meldrum and his Associates were pioneers in the study of group-I mGlu receptor antagonists in models of convulsive seizures. Intracerebroventricular (i.c.v.) injection of the selective orthosteric $\mathrm{mGlu}_{1}$ receptor antagonists, LY367385 ((+)-2-methyl-4-carboxyphenylglycine) and AIDA ((RS)-1-aminoindan-1,5-dicarboxylic acid), was protective against a generalized type of epilepsy with audiogenic seizures (DBA/2 mice). These two compounds could also reduce sound-induced clonic seizures when they were locally infused in the inferior colliculus of genetically epilepsy prone rats (GEPRs) [39]. Systemic administration of 2-methyl-6-(phenylethynyl)-pyridine (MPEP) or (E)-6-methyl2-styryl-pyridine (SIB-1893), which behave as potent and selective $\mathrm{mGlu}_{5}$ receptor negative allosteric modulators (NAMs), was also protective against sound-induced seizures in DBA/2 mice [40]. NAMs interact with allosteric sites of $\mathrm{mGlu}$ receptors inhibiting receptor activation regardless of the ambient concentrations of glutamate. The anti-seizure activity of $\mathrm{mGlu}_{5}$ receptor blockers was less prominent in the kindling model of epilepsy. Acute treatment with MPEP could reduce seizures and afterdischarge durations in kindled rats but only when combined with subprotective doses of valproate or phenobarbital [41]. As expected, molecules that antagonize both $\mathrm{mGlu}_{1}$ and $\mathrm{mGlu}_{5}$ receptors, such as LY393053 (2-amino-2-(3-cis and trans-carboxycyclobutyl)-3-(9H-thioxanthen-9-yl) propionic acid), LY339764 ((R.S)-2-amino-2-(4-carboxycyclobutyl-3-(9-xanthen-9-yl) propanoic acid), LY367335 (2-Amino-2-(3-cis and trans-carboxycyclobutyl)-3-(9H-xanthen-9-yl) propionic acid), LY367366 ((R,S)-2-amino2-(4-carboxyphenyl)-3-(9H-thioxanthen-9-yl) propanoic acid), and LY339840 ((R,S)-2-methyl-3-hydroxy-4-carboxyphenylglycine), were highly protective against limbic seizures induced by i.c.v. injection of the mixed $\mathrm{mGlu}_{1 / 5}$ receptor agonist, 3,5-dihydroxyphenylglycine (DHPG) [42]. Zavala-Tecuapetla et al. [43] examined the effect of the selective $\mathrm{mGlu}_{5}$ receptor NAM, 3-((2-methyl-4-thiazolyl)ethynyl)pyridine (MTEP), in an in vivo model of complex partial seizures based on repeated electrical stimulations of the dorsal hippocampus in rats. Treatment with MTEP suppressed epileptic after discharges in 12- and 18-day-old rats, but not in 25-day-old rats. Systemic treatment with the $\mathrm{mGlu}_{1}$ receptor orthosteric antagonist, AIDA, or with the $\mathrm{mGlu}_{5}$ receptor NAM, MPEP, was highly protective against audiogenic seizures in a genetic rat model of reflex epilepsy [44]. A decrease in seizure threshold for pentylenetetrazole (PTZ) during diazepam withdrawal was suppressed by i.c.v. pretreatment with the group I mGlu receptor antagonist, (S)-4-carboxyphenylglycine ((S)4CPG) [45]. In contrast, treatment with $\mathrm{mGlu}_{1}$ or $\mathrm{mGlu}_{5}$ receptor antagonists (EMQMCM ([3-ethyl-2-methyl-quinolin-6-yl-(4-methoxy-cyclohexyl)-methanone methanesulfonate]) and MPEP, respectively), did not produce robust anticonvulsant effects in the 6-Hz test and amygdaloid kindling, two models for difficult-to -treat secondarily generalized focal epilepsies [46]. Taken together, these data suggest that mGlu1 and mGlu5 receptors blockers are more effective in models of generalized convulsive epilepsies than in models of partial epilepsies. While all these data clearly demonstrate that endogenous activation of either $\mathrm{mGlu}_{1}$ or $\mathrm{mGlu}_{5}$ receptors facilitates the generation of convulsive seizures, genetic deletion of $\mathrm{mGlu}_{5}$ receptors did not protect against chemically induced seizures in mice [47]. In the same study, systemic treatment with MTEP did not reduce NMDA-induced seizures [47]. These findings do not support the hypothesis of a pro-convulsant activity of $\mathrm{mGlu}_{5}$ receptors in mice. Again, the complex role of mGlu receptors in the modulation of synaptic transmission may contribute to provide an explanation for these conflicting findings.

\subsection{Group-I mGlu receptors in models of absence epilepsy}

Expression and function of $\mathrm{mGlu}_{1}$ and $\mathrm{mGlu}_{5}$ receptors have been extensively investigated in a variety of experimental animal models of absence epilepsy. Absence seizures are non-convulsive seizures associated with bilateral symmetrical so-called 'generalized' spikeand-wave discharges (SWDs) at the electroencephalogram (EEG), which are generated by pathological oscillations of a corticothalamo-cortical neuronal network formed by the somatosensory cortex, the ventrobasal thalamic nuclei, and the reticular thalamic nuclei [48]. Both genetic epilepsy models and acute pharmacological seizure models of absence epilepsy are available. Rats of the Wistar Albino Glaxo/Rijswijk (WAG/Rij) strain represent a genetic absence model, and they develop spontaneous absence seizures after 2-3 months of age $[49,50]$. We have found that expression and function of $\mathrm{mGlu}_{1}$ receptors were reduced in the thalamus of symptomatic (8-month-old) WAG/Rij rats compared to both agematched non-epileptic control rats and young pre-symptomatic WAG/Rij rats [51]. These findings were confirmed by Karimzadeh et al. [52], who also found a reduction of $\mathrm{mGlu}_{1} \mathbf{1}$ receptor mRNA and protein levels in the thalamus of symptomatic WAG/Rij rats. Expression of $\mathrm{mGlu}_{1}$ receptors was also reduced in the hippocampus of double mutant (zi/zi, tm/tm) spontaneously epileptic rats, which exhibit both absence-like seizures and tonic convulsions [53]. Moving from the reduced $\mathrm{mGlu}_{1}$ receptor function found in the thalamus of symptomatic WAG/Rij rats, we have hypothesized that pharmacological enhancement of $\mathrm{mGlu}_{1}$ receptors could display 'therapeutic activity' against absence seizures. We tested this hypothesis using compound RO0711401 (9H-xanthene-9-carboxylic acid (4-trifluoromethyl-oxazol-2-yl) amide), which behaves as a selective and brain-permeant $\mathrm{mGlu}_{1}$ receptor positive allosteric modulator (PAM). mGlu receptor PAMs bind to a receptor site different than the glutamate recognition site (usually in the 7-TM domains) and amplify receptor response to glutamate acting in an activity-dependent manner. Systemic administration of low doses 
of RO0711401 ( 3 or $10 \mathrm{mg} / \mathrm{kg}$ ) significantly reduced the frequency of occurrence of SWDs in WAG/Rij rats, whereas higher doses (30 mg/kg) reduced both the frequency and the mean duration of SWDs. In contrast, administration of the $\mathrm{mGlu}_{1}$ receptor NAM, JNJ16259685 ((3,4-dihydro-2H-pyranol[2,3-b]quinolin-7yl) (cis-4-ethoxycycloexyl)methanone)) increased the frequency of SWD occurrence [51]. Similar data were obtained by Karimzadeh et al. [52], who found a reduction in the mean duration of SWDs after intrathalamic infusion of the $\mathrm{mGlu}_{1 / 5}$ receptor agonist, DHPG, and an increase in the duration and amplitude of SWDs after infusion of the mGlu ${ }_{1}$ antagonist, LY367385, in WAG/Rij rats. These findings suggest that $\mathrm{mGlu}_{1}$ receptors are candidate drug targets for the treatment of absence epilepsy. However, the evidence that the anti-absence activity of R00711401 was lost after the first two days of repeated administration [54] suggests the development of tolerance, which might be a major drawback in the therapeutic use of $\mathrm{mGlu}_{1}$ receptor PAMs. Our studies in WAG/ Rij rats indicate also that $\mathrm{mGlu}_{5}$ receptors are a more promising candidate drug target for the treatment of absence epilepsy. Similarl to $\mathrm{mGlu}_{1}$ receptors, the expression and function of $\mathrm{mGlu}_{5}$ were reduced in the thalamus of WAG/Rij rats. This reduction was also observed in pre-symptomatic WAG/Rij rats, suggesting that $\mathrm{mGlu}_{5}$ receptors lie at the core of the generation of absence seizures in this strain of rats [55]. Systemic administration of the $\mathrm{mGlu}_{5}$ receptor PAM, VU0360172 ((N-clyclobutyl-6-[2-3 (fluorophenyl) ethynyl] pyridine-3-carboxamine)), reduced both the frequency of occurrence and mean duration of SWDs in WAG/Rij rats, and its action was antagonized by the $\mathrm{mGlu}_{5}$ receptor NAM, MTEP [55]. Interestingly, no tolerance developed to the anti-absence activity of VU0360172, which was still visible after at least 10 days of repeated administrations [54]. We have further explored the mechanism responsible for the anti-absence activity of $\mathrm{mGlu}_{5}$ receptors by locally administering VU0360172 in the thalamus or somatosensory cortex of WAG/Rij rats. Injection in both anatomical sites resulted in a substantial anti-absence activity. In the cortex, the GABA transporter inhibitor tiagabine acted similar to the PAM, suggesting that the PAM enhanced GABA-ergic neurotransmission. Another interesting finding was obtained when VU0360172 was coinfused with the tiagabine, in the thalamus. Intrathalamic injection of tiagabine alone enhanced the frequency of occurrence of SWDs at doses of 1 or $2 \mu \mathrm{g} / \mu \mathrm{l}$ but was inactive at the dose of $0.5 \mu \mathrm{g} / \mu \mathrm{l}$. However, the inactive dose of tiagabine prevented the anti-absence effect caused by intrathalamic infusion of VU0360172 [56]. This suggested that the antiabsence activity of $\mathrm{mGlu}_{5}$ receptor activation in the ventrobasal thalamus was mediated by a mechanism that involved GABA transport. We now have evidence that pharmacological activation of $\mathrm{mGlu}_{5}$ receptors enhances the expression of the high-affinity GABA transporter, GAT-1, in the thalamus (Authors' unpublished observation), and we are currently exploring whether activation of $\mathrm{mGlu}_{5}$ receptors influences the mechanism of tonic synaptic inhibition, which relies on the availability of extrasynaptic GABA.

Studies performed in genetic mouse models of absence epilepsy do not support the hypothesis that $\mathrm{mGlu}_{1}$ or $\mathrm{mGlu}_{5}$ receptors should be activated to restrain absence seizures. Accordingly, treatment with $\mathrm{mGlu}_{1}$ or $\mathrm{mGlu}_{5}$ receptor antagonists reduced SWDs in lethargic (lh/lh) mice, which represent an atypical model of absence epilepsy $[39,40]$. In contrast, pharmacological blockade of $\mathrm{mGlu}_{5}$ receptors did not affect SWDs in an acute pharmacological model of absence epilepsy induced by low doses of PTZ in immature rats [57]. Contrasting data may originate from the use of different models and different drugs (for example, orthosteric vs. allosteric ligands).

\subsubsection{Group II mGlu receptors and convulsive seizures}

An increased expression of $\mathrm{mGlu}_{2 / 3}$ receptors (presumably $\mathrm{mGlu}_{3}$ receptors) has been reported in reactive astrocytes in a rat model of temporal lobe epilepsy induced by angular bundle electrical stimulation [34]. Transforming-growth factor- $\beta$ (TGF- $\beta$ ), a neuroprotective cytokine produced by astrocytes under the control of $\mathrm{mGlu}_{3}$ receptors [58], was also up-regulated throughout the hippocampus several days after induction of status epilepticus in rats [34]. In humans, an up-regulation of $\mathrm{mGlu}_{2 / 3}$ receptors was found in reactive astrocytes of patients with glioneuronal tumors or cortical focal dysplasia, two conditions associated with intractable epilepsy [59,60].

Analysis of $\mathrm{mGlu}_{2}$ and $\mathrm{mGlu}_{3}$ receptors in neurons showed a large reduction in the expression and function of both subtypes in the hippocampal dentate gyrus and cortex in the pilocarpine model of chronic epilepsy $24 \mathrm{~h}$ after the induction of status epilepticus (SE) [61]. The transcript of $\mathrm{mGlu}_{2}$ receptors was still down-regulated in the dentate gyrus of pilocarpinetreated rats two months after the onset of status epilepticus, whereas the transcript of $\mathrm{mGlu}_{3}$ receptors returned back to normal at this time point [62]. This raises the possibility that a long-lasting reduction in the expression and function of presynaptic $\mathrm{mGlu}_{2}$ receptors causes a sustained increase in glutamate release, thereby contributing to epileptogenesis in the hippocampus. In contrast, an up-regulation of $\mathrm{mGlu}_{3}$ receptors in reactive astrocytes might result in an enhanced production of TGF- $\beta$ [58] and other neurotrophic factors, thereby protecting neighbor neurons against seizure-induced damage.

Pharmacological data converge to demonstrate protective activity of group-II mGlu receptor agonists against convulsive seizures. Intracerebroventricular infusion of (S)-4-carboxy3-hydroxyphenylglycine [(S)-4C3HPG)], a mixed $\mathrm{mGlu}_{1}$ - receptor antagonist/mGlu $\mathrm{m}_{2}$ receptor agonist, dose-dependently antagonized pentylenetetrazol- and methyl-6,7-dimethoxy-4-ethyl-beta -carboline-2-carboxylate (DMCM)-induced clonic convulsions in

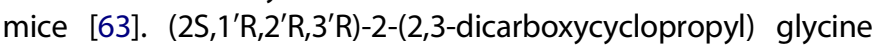
(DCG-IV), a group-II $\mathrm{mGlu}$ receptor agonist that also interacts with NMDA receptors, enhanced the threshold for generalized seizures in kindled rats [64], and attenuated kainate-induced limbic seizures [65].

Similar data were obtained by second-generation group-II mGlu receptor agonists, which display high potency, subtype-selectivity, and brain penetration. For example, the $\mathrm{mGlu}_{2 / 3}$ receptor agonist, (-)-2-oxa-4-aminobicyclo[3.1.0]hexane-4,6-dicarboxylate (LY379268), reduced the behavioral and electrographic course of acute status epilepticus induced by pilocarpine in mice [66]. LY354740, another potent $\mathrm{mGlu}_{2 / 3}$ agonist clinically developed for the treatment of generalized anxiety disorder [67], exerted a strong inhibition of epileptiform activity in rats by reducing the excitability of 
entorhinal neurons that are involved in the generation and propagation of epilepsy [68]; in addition, LY354740 enhanced the anticonvulsant effects of diazepam [69]. (2R,4R)4-Aminopyrrolidine-2,4-dicarboxylate (2R, 4R-APDC), another potent and selective $\mathrm{mGlu}_{2 / 3}$ receptor agonist, showed protective effects against pilocarpine-induced status epilepticus in adult rats [70].

Two elegant studies from the same research group [71,72] addressed the important issue of how group-II mGlu receptor ligands interact with classical anticonvulsant drugs using the 6- $\mathrm{Hz}$ model of psychomotor seizures in mice. In the first study [71] the Authors were able to demonstrate a pharmacological synergism between levetiracetam and three drugs that activate $\mathrm{mGlu}_{2}$ receptors: the selective $\mathrm{mGlu}_{2}$ receptor PAMs, JNJ42153605 (3-(Cyclopropylmethyl)-7-(4-phenyl-1-piperidinyl)-8-(trifluoromethyl) [1,2,4]triazolo[4,3-a]pyridine) and JNJ-40411813 (1-butyl-3-chloro-4-(4-phenyl-1-piperidinyl)-(1H)-pyridone), and the potent $\mathrm{mGlu}_{2 / 3}$ receptor agonist, LY404039 ((1R,4S,5S,6S)4-amino-2-thiabicyclo[3.1.0]hexane-4,6-dicarboxylic acid 2,2-dioxide). Subthreshold doses of the three $\mathrm{mGlu}_{2}$ receptor ligands increased the potency of levetiracetam by $>25$ fold, whereas a moderately effective dose of levetiracetam increased the potency of JNJ-40411813 by more than 10 fold. This likely reflected a pharmacodynamic interaction because plasma levels of levetiracetam and JNJ-40411813 did not differ when the two drugs were administered in combination [71]. In the second study [72], the Authors confirmed the pharmacodynamic synergism between JNJ-46356479 (8-Trifluoromethyl-3-cyclopropylmethyl-7-[(4-(2,4difluorophenyl)-1-piperazinyl)methyl]-1,2,4-triazolo[4,3-a]pyridine) and levetiracetam in the $6-\mathrm{Hz}$ test with the aid of isobolographic analysis, and could also demonstrate a synergism of the two drugs in the corneal kindling model. Interestingly, there was no synergism between JNJ-40411813 and lamotrigine or valproate, two drugs that share the ability to inhibit voltage-sensitive sodium channels. These studies have a high translational value suggesting that drugs that activate $\mathrm{mGlu}_{2}$ receptors may lower the required effective dose of levetiracetam, therefore optimizing the risk-tobenefit ratio of levetiracetam in the treatment of temporal lobe epilepsy and perhaps other types of epilepsy. Interestingly, JNJ40411813 (ADX-71149) is currently being prepared for a Phase 2 clinical study by Addex Therapeutics and Janssen Pharmaceuticals for the treatment of epilepsy.

\subsubsection{Group-II mGlu receptors in models of absence epilepsy}

As opposed to findings obtained in models of convulsive seizures, the role of $\mathrm{mGlu}_{2 / 3}$ receptors in models of absence epilepsy is controversial. Using lethargic mice to model absence epilepsy, Brian Meldrum and his Associates have found that treatment with the selective $\mathrm{mGlu}_{2 / 3}$ receptor agonists LY379268 and (-)-2-thia-4 aminobicyclo[3.1.0]hexane-4,6-dicarboxylate (LY389795) reduced SWD duration [73].

In contrast, we have found that systemic treatment with LY379268 enhanced, whereas the preferential $\mathrm{mGlu}_{2 / 3}$ receptor antagonist, LY341495 ((2S)-2-amino-2-[(1S,2S)-2-carboxycycloprop-1-yl]-3-(xanth-9-yl) propanoic acid), reduced, the number of SWDs in the WAG/Rij rat model [74]. The contrasting findings obtained in two different models of absence epilepsy $[73,74]$ are difficult to explain. Traditionally, $\mathrm{mGlu}_{2}$ and $\mathrm{mGlu}_{3}$ receptors have been considered as presynaptic receptors negatively modulating neurotransmitter release. However, recent findings suggest that $\mathrm{mGlu}_{3}$ receptors are also found in postsynaptic elements, where they functionally interact with $\mathrm{mGlu}_{5}$ receptors. Activation of $\mathrm{mGlu}_{3}$ receptors boost $\mathrm{mGlu}_{5}$ receptor signaling, and $\mathrm{mGlu}_{3}$ receptordependent long-term depression in the prefrontal cortex requires the endogenous activation of $\mathrm{mGlu}_{5}$ receptors [12]. It is possible that differences in the expression and/or function of $\mathrm{mGlu}_{2}$ and $\mathrm{mGlu}_{3}$ receptors in the cortico-thalamocortical network underlying SWDs in lethargic mice, and WAG/Rij rats contributes to the different outcome of treatments with $\mathrm{mGlu}_{2 / 3}$ receptor agonists. Experiments with subtype-selective modulators (selective PAMs or NAMs of $\mathrm{mGlu}_{2}$ and $\mathrm{mGlu}_{3}$ receptors) should be carried out to unravel the precise role played by either receptor subtypes in the two models of absence epilepsy.

\subsection{Group-III mGlu receptors and convulsive seizures}

For many years, the study of group III mGlu receptors in epilepsy has been hampered by the lack of subtype-selective ligands. More recently, the development of both orthosteric and allosteric ligands targeting individual group-III mGlu receptor subtypes has encouraged investigation of these receptors in CNS disorders, including epilepsy [75]. A role for group-III mGlu receptors in epilepsy is suggested by the evidence that changes in the transcripts of $\mathrm{mGlu}_{4}$ receptors are found in the hippocampal dentate gyrus of mice developing limbic seizures in response to pilocarpine. Interestingly, increases in $\mathrm{mGlu}_{4}$ receptor mRNA levels were found in CD1 mice, but not in FVB/N mice, which are more susceptible to pilocarpine-induced seizures. Hence, it has been speculated that $\mathrm{mGlu}_{4}$ receptors might have a protective role against limbic convulsive seizures in the pilocarpine SE mode [76]. However, this interpretation is not in line with pharmacological data showing that i.c.v. treatments with L-2-amino-4-phosphonobutanoate (L-AP4) and L-serine-O-phosphate (L-SOP) (the two prototypical orthosteric agonists of all group-III mGlu receptor subtypes) are pro-convulsant in both nonepileptic Swiss-Webster and epileptic DBA/2 mice [77]. Curiously, i.c.v. administration of non-subtype-selective group-III mGlu receptors antagonists also produced pro-convulsant effects in these mice [77]. Similar findings were obtained with the $\mathrm{mGlu}_{4}$ receptor PAM, N-phenyl-7-(hydroxyimino)cyclopropa[b] chromen-1a-carboxamide (PHCCC), in three models of epileptic seizures in immature rats: $\mathrm{PHCCC}$ potentiated the effect of a sub-convulsant dose of PTZ, significantly prolonged the duration of PTZ-induced rhythmic activity episodes, and shortened the intervals between individual episodes [78].

In other studies, pharmacological activation of group-III mGlu receptors produced anticonvulsant effects. For example, the group-III mGlu receptor agonist, ACPT-1 ((1S,3R,4S)-1-aminocyclopentane-1,2,4-tricarboxylic acid), reduced DHPG-induced seizures in rats and sound-induced seizures in both DBA/2 mice and genetically epilepsy-prone (GEP) rats [79]. Another group-III agonist, $(\mathrm{R}, \mathrm{S})$-4-phosphonophenylglycine (PPG), displayed anticonvulsant 
activity, and its action was abrogated in mice lacking $\mathrm{mGlu}_{7}$ receptors [80]. (S)-3,4-dicarboxyphenylglycine (DCPG), a selective agonist of $\mathrm{mGlu}_{8}$ receptors, was able to reduce DL-homocysteic acid-induced seizures and to suppress clonic-tonic seizures [81]. In addition, a down-regulation of $\mathrm{mGlu}_{8}$ receptors has been detected in pilocarpine-epileptic rats [82]. Clearly, the role played by groupIII mGlu receptor subtypes in the regulation of convulsive seizures is not homogeneous, and off-target effects of agonists and antagonists used in the various studies cannot be ruled out. While it appears that $\mathrm{mGlu}_{8}$ and $\mathrm{mGlu}_{7}$ receptors display anticonvulsant properties, the role of $\mathrm{mGlu}_{4}$ receptors in the pathophysiology and control of convulsive seizures remains controversial.

\subsubsection{Group-III mGlu receptors in models of absence epilepsy}

A series of findings combining electrophysiological analysis in thalamic neurons, preclinical models, and genetic studies in humans suggest that $\mathrm{mGlu}_{4}$ and $\mathrm{mGlu}_{7}$ receptors are involved in the pathophysiology of absence seizures and can be targeted by therapeutic interventions (reviewed by Ngomba et al. [83]). A pro-absence activity of $\mathrm{mGlu}_{4}$ receptors is suggested by the evidence that $\mathrm{mGlu}_{4}$ receptor knockout mice are resistant to absence seizures evoked by low doses of PTZ, whereas local injection of a $\mathrm{mGlu}_{4}$ receptor agonist in wildtype mice exacerbated pharmacologically induced absence seizures [84]. This hypothesis is supported by our studies in WAG/Rij rats, which showed an increased expression of $\mathrm{mGlu}_{4}$ receptors in the reticular thalamic nucleus as compared to non-epileptic control rats [85]. In symptomatic WAG/Rij rats, systemic administration of the $\mathrm{mGlu}_{4}$ receptor PAM, PHCCC, enhanced the incidence of SWDs [85]. Interestingly, polymorphic variants of GRM4, the gene encoding for the $\mathrm{mGlu}_{4}$ receptor, have been associated with juvenile myoclonic epilepsy (JME), an epileptic syndrome belonging to the group of genetic generalized epilepsies and characterized, inter alia, by the occurrence of absence seizures [86-88].

The $\mathrm{mGlu}_{7}$ receptor may play a central role in the pathophysiology of thalamo-cortical oscillations underlying SWDs and absence seizures. Federica Bertaso and her Associates from the Institute of Functional Genomics in Montpellier (France) have shown that genetic or pharmacological disruption of the $\mathrm{mGlu}_{7}$ receptor or its PDZ-interacting protein, protein interacting with $C$ kinase 1 (PICK1), causes behavioral and EEG manifestations typical of absence epilepsy [89]. Mice lacking the PDZ domain of $\mathrm{mGlu}_{7}$ receptors are also more susceptible to absence seizures induced by low doses of PTZ [90]. These findings laid the groundwork for an in-depth study of the role played by $\mathrm{mGlu}_{7}$ receptors in the pathophysiology of the cortico-thalamo-cortical network. By combining optogenetics, electrophysiological recordings, and pharmacology, Tassin et al. [91] have found that $\mathrm{mGlu}_{7}$ receptors are presynaptically localized in both glutamaterigc and GABAergic terminals, where they inhibit neurotransmitter release and short-term synaptic plasticity. Similar findings were obtained in vitro by Kyuyong and Huguenard [92], who found that high concentrations of L-AP4, which likely recruit $\mathrm{mGlu}_{7}$ receptors at reticular thalamic-ventrobasal thalamic synapses, inhibit pathological oscillations underlying absence seizures. Selective pharmacological blockade of $\mathrm{mGlu}_{7}$ receptors with the NAM, ADX71743 (6-(2,4-dimethylphenyl)-2-ethyl-6,7-dihydrobenzo[d]
oxazol-4(5H)-one), enhanced synaptic transmission in the thalamus inducing SWDs at the EEG, and behavioral arrest [91]. Taken together, these findings raise the interesting possibility that functional alterations in $\mathrm{mGlu}_{7}$ receptors cause pathological oscillations within the cortico-thalamo-cortical network underlying absence seizures and that drugs that selectively enhance $\mathrm{mGlu}_{7}$ receptor function might be therapeutically helpful against absence epilepsy.

\section{Conclusion}

After many years of extensive research, it is frustrating that no mGlu receptor ligands are present in the drug market, as yet. However, many subtype-selective ligands are still under development for the treatment of CNS disorders, and the hope that some of them will be soon available for human use is still alive. A synopsis of studies showing protective effects with mGlu receptor ligands in experimental animal models of epilepsy is shown in Table 1. Synaptic localization and function of individual mGlu receptor subtypes are shown in Figure 1. $\mathrm{mGlu}_{5}$ receptor NAMs appear to be promising candidates for the treatment of convulsive epileptic syndromes, whereas, in our opinion, $\mathrm{mGlu}_{5}$ receptor PAMs may enrich the therapeutic armamentarium for the treatment of absence epilepsy. It is more often the case that anti-epileptic drugs have opposite effects on convulsive and non-convulsive epilepsies. A potential drawback in the use of $\mathrm{mGlu}_{5}$ receptor NAMs is cognitive dysfunction, which might result from an impairment of activity-dependent synaptic plasticity. In contrast, the neuroprotective activity of $\mathrm{mGlu}_{5} \mathrm{NAMs}$ (reviewed by Nicoletti et al. [9]; Bruno et al. [24]) might restrain excitotoxic neuronal death occurring in some epileptic syndrome (e.g., temporal lobe epilepsy associated with Ammon's horn sclerosis). The evidence that $\mathrm{mGlu}_{5}$ receptors are anatomically and functionally linked to NMDA receptors raises the possibility that a prolonged use of high doses of $\mathrm{mGlu}_{5}$ NAMs may cause neurodegeneration and psychotomimetic effects [93], which would seriously limit the development of these drugs in the treatment of absence epilepsy. The use of biased mGlu ${ }_{5}$ PAMs, which amplify $\mathrm{mGlu}_{5}$ receptor function without potentiating NMDA receptor activity [94], may help overcome this limitation. The elucidation of the precise mechanisms whereby $\mathrm{mGlu}_{5}$ receptors restrain pathological oscillation within the corticothalamo-cortical network will give the impetus for the development of $\mathrm{mGlu}_{5}$ receptor PAMs for the treatment of absence epilepsy. Moreover, studies aimed towards antiepileptogenesis in absence models (or in any other model for epileptogenesis), as recently reviewed [95], using $\mathrm{mGlu}_{5}$ PAMs are still lacking. Preclinical data are still insufficient to conclude that $\mathrm{mGlu}_{2 / 3}$ ligands could be promising candidate drug targets for the treatment of convulsive or absence epilepsy. However, the pharmacodynamic synergism between $\mathrm{mGlu}_{2}$ receptor PAMs and levetiracetam [71,72] holds promise from a therapeutic standpoint. The recent availability of $\mathrm{mGlu}_{2^{-}}$and $\mathrm{mGlu}_{3}$-selective NAMs will help to elucidate the precise role of the two receptor subtypes in the pathophysiology of epilepsy [96-99].

In contrast, $\mathrm{mGlu}_{7}$ receptors appear to be tightly linked to the pathophysiology of absence epilepsy (at least in animal models), and, this encourages the development of selective $\mathrm{mGlu}_{7}$ receptor agonists or PAMs for the treatment of this disorder. 
Table 1. Synopsis of studies showing protection with mGlu receptor ligands in experimental animal models of epilepsy.

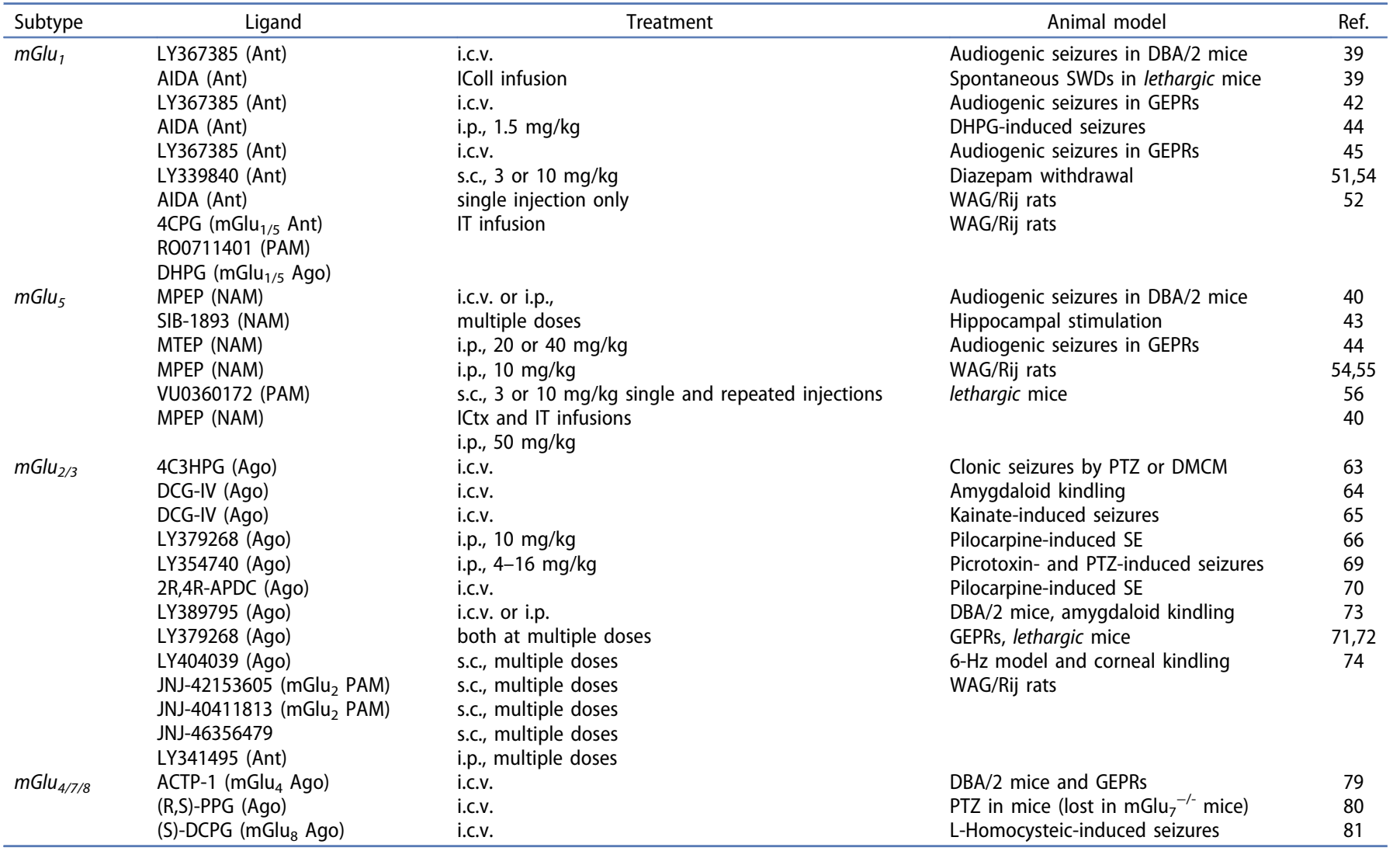

Only studies showing protection against seizures with mGlu receptor ligands are reported. For studies showing no effect or aggravation of seizures, see the appropriate sections in the text.

Ago = orthosteric agonist; Ant $=$ orthosteric antagonist; i.c.v. = intracerebroventricular infusion; i.p. = intraperitoneal injection; IColl infusion = infusion in the inferior colliculus; ICtx infusion = intracortical infusion; IT infusion = intrathalamic infusion; NAM = negative allosteric modulator; PAM = positive allosteric modulator; s.c. = subcutaneous administration.

For abbreviations and molecular structures of mGlu receptor ligands and other drugs, see appropriate sections in the text.

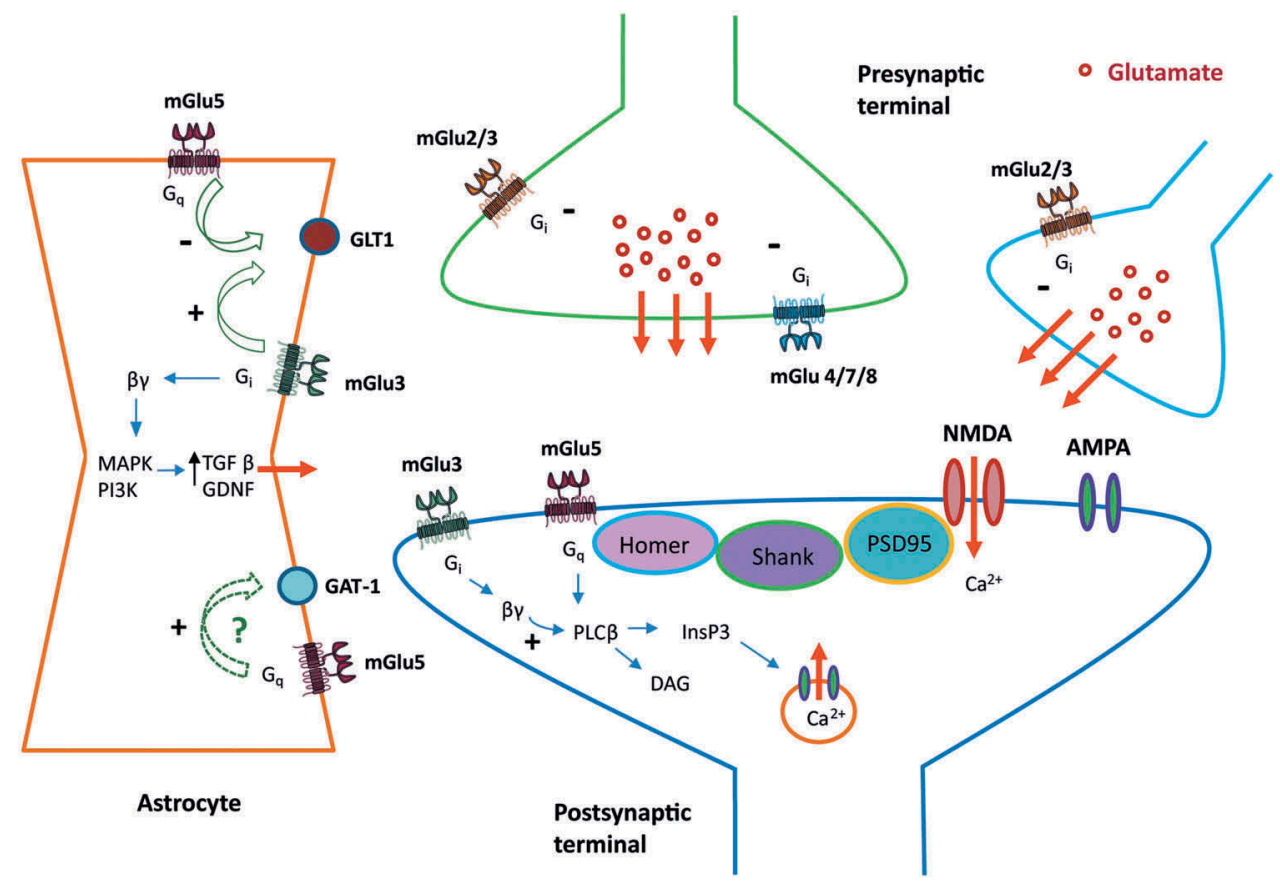

Figure 1. Synaptic localization and function of individual mGlu receptor subtypes.

Negative modulation of glutamate release by $\mathrm{mGlu}_{2}$ receptors contributes to explain the encouraging data obtained with $\mathrm{mGlu}_{2}$ receptor PAMs in models of convulsive seizures [71,72]. $\mathrm{mGlu}_{5}$ receptor NAMs may restrain convulsive seizures by inhibiting postsynaptic mGlu 5 receptors, which are functionally linked to NMDA receptors (see main text). Positive modulation of GAT-1 receptors by mGlu ${ }_{5}$ receptors PAMs is hypothetical and contributes to explain the protective activity of mGlu 5 receptor PAMs in the WAG/Rij rat model of absence epilepsy (see main text). For a more detailed representation of the role played by individual mGlu receptor subtypes in the regulation of the cortico-thalamo-cortical network underlying absence seizures, see Ref [83]. and [101]. 


\section{Expert opinion}

Although glutamate is a main player of over-excitation in epilepsy, glutamate receptor antagonists were not successfully developed as antiepileptic drugs, with the notable exception of perampanel. One of the reasons is that iGlu receptor antagonists are not disease-dependent and cause a widespread inhibition of excitatory synaptic transmission in the CNS. In addition, NMDA receptor antagonists impair mechanisms of activity-dependent synaptic plasticity and may cause psychotomimetic effects. Targeting mGlu receptors with subtype-selective ligands (particularly, PAMs and NAMs) might offer a more favorable outcome in the treatment of epilepsy because mGlu receptors do not mediate, but rather modulate, synaptic transmission. Using these drugs, we expect a greater selectivity for overexcited neuronal networks (for example, the action of PAMs is activitydependent), and a better profile of safety and tolerability.

Metabotropic glutamate $(\mathrm{mGlu})$ receptors were discovered in 1985. Since then, they have attracted the interest of neuroscientists in many different fields with great potential as candidate drug targets for the treatment of CNS disorders. Preclinical data and clinical studies carried out in CNS disorders other than epilepsy indicate, in general, a good profile of safety and tolerability for most mGlu receptor ligands, and this strengthens the potential value of these drugs in the treatment of epilepsy.

Drugs that inhibit $\mathrm{mGlu}_{1}$ and $\mathrm{mGlu}_{5}$ receptors (either NAMs or orthosteric antagonists) have consistently shown protective activity in models of convulsive epilepsy. However, the potential detrimental effects of $\mathrm{mGlu}_{1}$ receptor antagonists on cerebellar function [100] and the impact of $\mathrm{mGlu}_{5}$ NAMs on mechanisms of activity-dependent synaptic plasticity (see above) may limit the use of these drugs in the treatment of epilepsy. The exciting data obtained with the $6-\mathrm{Hz}$ model of psychomotor seizures [71,72] suggest that $\mathrm{mGlu}_{2}$ receptor PAMs are promising candidate drugs for the treatment of focal epilepsy and may act synergistically with levetiracetam, one of the most widely used drugs in epilepsy. Although the molecular nature of this pharmacodynamics interaction is unknown, these findings are highly promising from a therapeutic standpoint.

Our data obtained in WAG/Rij rats (a well-developed and validated model of absence epilepsy) encourage the development of $\mathrm{mGlu}_{5}$ PAMs for the treatment of absence seizures. These drugs might act by enhancing GABA reuptake in ventrobasal thalamic nuclei. These drugs suppress SWDs both in cortex and in thalamus. In the cortex by stimulating GABA-ergic interneurons, in the ventrobasal thalamic nuclei by enhancing GABA-ergic reuptake. mGlu ${ }_{5}$ PAMs are under development for the treatment of schizophrenia and display cognitive enhancing effects in rodents. Stimulus-biased $\mathrm{mGlu}_{5}$ receptor PAMs that do not activate NMDA receptors show no neurotoxic effects in rodents and are particularly promising from a therapeutic standpoint. We predict that drugs that selectively activate $\mathrm{mGlu}_{7}$ receptors are effective in the treatment of absence epilepsy. Both $\mathrm{mGlu}_{5}$ and $\mathrm{mGlu}_{7}$ PAMs might be clinically helpful in patients that are refractory to conventional medications and require polytherapy for an adequate control of absence seizures. Thus, the study of mGlu receptors in epilepsy represents an exciting example of translational research that holds promise for the treatment of one of the most common CNS disorders which is a high social and economic burden worldwide.

A dark side is that the role of mGlu receptors in mechanisms of epileptogenesis is lacking, and, in general, most of the existing data were obtained after acute or temporally restricted administration of mGlu receptor ligands, whereas drug treatment of epilepsy in humans usually lasts for several months or years (except for emergency treatment of SE). It will be extremely interesting to examine the effect of $\mathrm{mGlu}$ receptor ligands on epileptogenesis in genetic and kindling models of epilepsy, and to investigate whether chronic treatments with these drugs restrains the development or recurrence of seizures (for example, by treating pre-symptomatic WAG/Rij rats with $\mathrm{mGlu}_{5}$ receptor PAMs or by administering appropriate receptor ligands after SE during the so-called 'silent' period in the pilocarpine and kainic acid models).

\section{Funding}

This work was funded by The Italian Ministry of Health.

\section{Declaration of interest}

The authors have no relevant affiliations or financial involvement with any organization or entity with a financial interest in or financial conflict with the subject matter or materials discussed in the manuscript. This includes employment, consultancies, honoraria, stock ownership or options, expert testimony, grants or patents received or pending, or royalties.

\section{Reviewer disclosures}

Peer reviewers on this manuscript have no relevant financial or other relationships to disclose.

\section{References}

Papers of special note have been highlighted as either of interest $(\cdot)$ or of considerable interest $(\cdot \bullet)$ to readers.

1. Tsai JJ, Wu T, Leung $H$, et al. Perampanel, an AMPA receptor antagonist: from clinical research to practice in clinical settings. Acta Neurol Scand. 2018 Apr;137(4):378-391.

2. Mayer ML, Westbrook GL. Permeation and block of N-methylD-aspartic acid receptor channels by divalent cations in mouse cultured central neurones. J Physiol. 1987 Dec;394:501-527.

- A seminal article describing the inhibitory action of $\mathrm{Mg}^{2+}$ on the NMDA-gated ion channel.

3. Johnson JW, Ascher P. Glycine potentiates the NMDA response in cultured mouse brain neurons. Nature. 1987 Feb 5-11;325 (6104):529-531.

-. The first article describing the activity of glycine as a co-agonist of NMDA receptors.

4. Collingridge GL, Bliss TV. Memories of NMDA receptors and LTP. Trends Neurosci. 1995 Feb;18(2):54-56.

- An excellent review describing the role of NMDA receptors in the induction of LTP.

5. Meador KJ. The basic science of memory as it applies to epilepsy. Epilepsia. 2007;48(Suppl 9):23-25.

6. Meldrum BS. The role of glutamate in epilepsy and other CNS disorders. Neurology. 1994 Nov;44(11 Suppl 8):S14-23. 
- An excellent review on metabotropic glutamate receptors and epilepsy by a leading research group in the field.

7. Lodge $D$, Mercier MS. Ketamine and phencyclidine: the good, the bad and the unexpected. Br J Pharmacol. 2015 Sep;172 (17):4254-4276.

8. Bruno V, Battaglia G, Copani A, et al. Metabotropic glutamate receptor subtypes as targets for neuroprotective drugs. J Cereb Blood Flow Metab. 2001 Sep;21(9):1013-1033.

9. Nicoletti F, Bockaert J, Collingridge GL, et al. Metabotropic glutamate receptors: from the workbench to the bedside. Neuropharmacology. 2011 Jun;60(7-8):1017-1041.

10. Niswender CM, Conn PJ. Metabotropic glutamate receptors: physiology, pharmacology, and disease. Annu Rev Pharmacol Toxicol. 2010;50:295-322.

11. Conn PJ, Pin JP. Pharmacology and functions of metabotropic glutamate receptors. Annu Rev Pharmacol Toxicol. 1997;37:205-237.

12. Di Menna $L$, Joffe $M E$, lacovelli $L$, et al. Functional partnership between mGlu3 and mGlu5 metabotropic glutamate receptors in the central nervous system. Neuropharmacology. 2018 Jan;128: 301-313.

- An interesting article describing a novel and unexpected function of mGlu3 receptors in the CNS.

13. Pinheiro PS, Mulle C. Presynaptic glutamate receptors: physiological functions and mechanisms of action. Nat Rev Neurosci. 2008 Jun;9(6):423-436.

14. Feng $Z, M a S, H u$ G, et al. Allosteric binding site and activation mechanism of class C G-protein coupled receptors: metabotropic glutamate receptor family. Aaps J. 2015 May;17(3):737-753.

15. Kunishima N, Shimada Y, Tsuji Y, et al. Structural basis of glutamate recognition by a dimeric metabotropic glutamate receptor. Nature. 2000 Oct 26;407(6807):971-977.

- A breakthrough article in the field of metabotropic glutamate receptors.

16. Muto T, Tsuchiya D, Morikawa K, et al. Structures of the extracellular regions of the group II/III metabotropic glutamate receptors. Proc Natl Acad Sci U S A. 2007 Mar 6;104(10):3759-3764.

17. Nicoletti F, Bruno V, Ngomba RT, et al. Metabotropic glutamate receptors as drug targets: what's new? Curr Opin Pharmacol. 2015;20:89-94.

18.. Rout SK, Kar DM. A review on antiepileptic agents, current research and future prospectus on conventional and traditional drugs. Int J Pharma Sci Rev Res. 2010;3:19-23.

19. Anovadiya AP, Sanmukhani JJ, Tripathi CB. Epilepsy: novel therapeutic targets. J Pharmacol Pharmacother. 2012 Apr;3(2):112-117.

20. Lasoń W, Chlebicka M, Rejdak K. Research advances in basic mechanisms of seizures and antiepileptic drug action. Pharmacol Rep. 2013;65(4):787-801.

21. Hovelsø N, Sotty F, Montezinho LP, et al. Therapeutic potential of metabotropic glutamate receptor modulators. Curr Neuropharmacol. 2012 Mar;10(1):12-48.

22. Chapman AG. Glutamate receptors in epilepsy. Prog Brain Res. 1998;116:371-383.

23. Moldrich RX, Beart PM. Emerging signalling and protein interactions mediated via metabotropic glutamate receptors. Curr Drug Targets CNS Neurol Disord. 2003 Apr;2(2):109-122.

24. Bruno V, Caraci F, Copani A, et al. The impact of metabotropic glutamate receptors into active neurodegenerative processes: A "dark side" in the development of new symptomatic treatments for neurologic and psychiatric disorders. Neuropharmacology. 2017 Mar;15(115):180-192.

25. Werner FM, Coveñas R. Classical neurotransmitters and neuropeptides involved in generalized epilepsy: a focus on antiepileptic drugs. Curr Med Chem. 2011;18(32):4933-4948.

26. Werner FM, Coveñas R. Classical neurotransmitters and neuropeptides involved in generalized epilepsy in a multi-neurotransmitter system: how to improve the antiepileptic effect? Epilepsy Behav. 2017 Jun;71(Pt B):124-129.

27. Qian F, Tang FR. Metabotropic glutamate receptors and interacting proteins in epileptogenesis. Curr Neuropharmacol. 2016; 14(5):551-562.
28. Tang FR, Bradford HF, Ling EA. Metabotropic glutamate receptors in the control of neuronal activity and as targets for development of anti-epileptogenic drugs. Curr Med Chem. 2009;16 (17):2189-2204.

29. Alexander GM, Godwin DW. Metabotropic glutamate receptors as a strategic target for the treatment of epilepsy. Epilepsy Res. 2006 Sep;71(1):1-22.

30. Ure J, Baudry M, Perassolo M. Metabotropic glutamate receptors and epilepsy. J Neurol Sci. 2006 Aug 15;247(1):1-9. Epub 2006 May 11

31. Moldrich RX, Chapman AG, De Sarro G, et al. Glutamate metabotropic receptors as targets for drug therapy in epilepsy. Eur J Pharmacol. 2003 Aug 22;476(1-2):3-16.

32. Doherty J, Dingledine R. The roles of metabotropic glutamate receptors in seizures and epilepsy. Curr Drug Targets CNS Neurol Disord. 2002 Jun;1(3):251-260.

33. Wong RK, Bianchi R, Taylor GW, et al. Role of metabotropic glutamate receptors in epilepsy. Adv Neurol. 1999;79:685-698.

34. Aronica $E$, van Vliet EA, Mayboroda OA, et al. Upregulation of metabotropic glutamate receptor subtype mGluR3 and mGluR5 in reactive astrocytes in a rat model of mesial temporal lobe epilepsy. Eur J Neurosci. 2000 Jul;12(7):2333-2344.

35. Tang FR, Lee WL, Yeo TT. Expression of the group I metabotropic glutamate receptor in the hippocampus of patients with mesial temporal lobe epilepsy. J Neurocytol. 2001 May;30(5):403-411.

36. Blümcke I, Becker AJ, Klein C, et al. Temporal lobe epilepsy associated up-regulation of metabotropic glutamate receptors: correlated changes in mGluR1 mRNA and protein expression in experimental animals and human patients. J Neuropathol Exp Neurol. 2000 Jan;59(1):1-10.

37. Notenboom RG, Hampson DR, Jansen GH, et al. Up-regulation of hippocampal metabotropic glutamate receptor 5 in temporal lobe epilepsy patients. Brain. 2006 Jan;129(Pt 1):96-107.

38. Kandratavicius L, Rosa-Neto P, Monteiro MR, et al. Distinct increased metabotropic glutamate receptor type 5 (mGluR5) in temporal lobe epilepsy with and without hippocampal sclerosis. Hippocampus. 2013 Dec;23(12):1212-1230.

39. Chapman AG, Yip PK, Yap JS, et al. Anticonvulsant actions of LY 367385 ((+)-2-methyl-4-carboxyphenylglycine) and AIDA ((RS)-1-aminoindan-1,5-dicarboxylic acid). Eur J Pharmacol. 1999 Feb 26;368(1):17-24.

40. Chapman AG, Nanan K, Williams M, et al. Anticonvulsant activity of two metabotropic glutamate group I antagonists selective for the mGlu5 receptor: 2-methyl-6-(phenylethynyl)-pyridine (MPEP), and (E)-6-methyl-2-styryl-pyridine (SIB 1893). Neuropharmacology. 2000 Jul 10;39(9):1567-1574

41. Borowicz KK, Łuszczki JJ, Czuczwar SJ. 2-Methyl-6-phenylethynylpyridine (MPEP), a non-competitive mGluR5 antagonist, differentially affects the anticonvulsant activity of four conventional antiepileptic drugs against amygdala-kindled seizures in rats. Pharmacol Rep. 2009 Jul-Aug;61(4):621-630.

42. Kingston $A E$, Griffey $K$, Johnson $M P$, et al. Inhibition of group I metabotropic glutamate receptor responses in vivo in rats by a new generation of carboxyphenylglycine-like amino acid antagonists. Neurosci Lett. 2002 Sep 20;330(2):127-130.

43. Zavala-Tecuapetla C, Kubová H, Otáhal J, et al. Age-dependent suppression of hippocampal epileptic afterdischarges by metabotropic glutamate receptor 5 antagonist MTEP. Pharmacol Rep. 2014 Oct;66(5):927-930.

44. Bashkatova VG, Sudakov SK, Prast H. Antagonists of metabotropic glutamate receptors prevent the development of audiogenic seizures. Bull Exp Biol Med. 2015 May;159(1):1-3.

45. Suzuki T, Shimizu N, Tsuda M, et al. Role of metabotropic glutamate receptors in the hypersusceptibility to pentylenetetrazole-induced seizure during diazepam withdrawal. Eur J Pharmacol. 1999 Mar 19:369(2):163-168

46. Löscher W, Dekundy A, Nagel J, et al. mGlu1 and mGlu5 receptor antagonists lack anticonvulsant efficacy in rodent models of difficult-to-treat partial epilepsy. Neuropharmacology. 2006 Jun;50 (8):1006-1015. 
47. Witkin JM, Baez M, Yu J, et al. mGlu5 receptor deletion does not confer seizure protection to mice. Life Sci. 2008 Aug 29;83 (9-10):377-380.

48. Blumenfeld $H$. Cellular and network mechanisms of spike-wave seizures. Epilepsia. 2005;46(Suppl 9):21-33.

- An excellent review article on the network mechanisms underlying absence epilepsy.

49. Schridde $U$, van Luijtelaar $G$. The role of the environment on the development of spike-wave discharges in two strains of rats. Physiol Behav. 2005 Mar 16;84(3):379-386.

50. van Luijtelaar G, Sitnikova E, Luttjohann A. On the origin and suddenness of absences in genetic absence models. Clin EEG Neurosci. 2011 Apr;42(2):83-97.

51. Ngomba RT, Santolini I, Biagioni F, et al. Protective role for type-1 metabotropic glutamate receptors against spike and wave discharges in the WAG/Rij rat model of absence epilepsy. Neuropharmacology. 2011 Jun;60(7-8):1281-1291.

52. Karimzadeh F, Modarres Mousavi SM, Ghadiri T, et al. The modulatory effect of metabotropic glutamate receptor type-1a on spikewave discharges in WAG/Rij rats. Mol Neurobiol. 2017 Mar;54 (2):846-854.

53. Guo F, Sun F, Yu JL, et al. Abnormal expressions of glutamate transporters and metabotropic glutamate receptor 1 in the spontaneously epileptic rat hippocampus. Brain Res Bull. 2010 Mar 16;81 (4-5):510-516.

54. D'Amore V, Santolini I, Celli R, et al. Head-to head comparison of mGlu1 and mGlu 5 receptor activation in chronic treatment of absence epilepsy in WAG/Rij rats. Neuropharmacology. 2014;85:91-103.

55. D'Amore V, Santolini I, van Rijn CM, et al. Potentiation of mGlu5 receptors with the novel enhancer, VU0360172, reduces spontaneous absence seizures in WAG/Rij rats. Neuropharmacology. 2013 Mar;66:330-338.

- First evidence that pharmacological activation of mGlu5 receptors reduces spike-and-wave discharges in a rat model of absence epilepsy.

56. D'Amore V, von Randow C, Nicoletti F, et al. Anti-absence activity of mGlu1 and mGlu5 receptor enhancers and their interaction with a GABA reuptake inhibitor: effect of local infusions in the somatosensory cortex and thalamus. Epilepsia. 2015 Jul;56(7):1141-1151.

57. Lojková D, Mares P. Anticonvulsant action of an antagonist of metabotropic glutamate receptors mGluR5 MPEP in immature rats. Neuropharmacology. 2005;49(Suppl 1):219-229.

58. Bruno V, Battaglia G, Casabona G, et al. Neuroprotection by glial metabotropic glutamate receptors is mediated by transforming growth factor-beta. J Neurosci. 1998 Dec 1;18(23):9594-9600.

59. Aronica $\mathrm{E}$, Yankaya $\mathrm{B}$, Jansen $\mathrm{GH}$, et al. Ionotropic and metabotropic glutamate receptor protein expression in glioneuronal tumours from patients with intractable epilepsy. Neuropathol Appl Neurobiol. 2001 Jun;27(3):223-237.

60. Aronica E, Gorter JA, Jansen GH, et al. Expression and cell distribution of group I and group II metabotropic glutamate receptor subtypes in taylor-type focal cortical dysplasia. Epilepsia. 2003 Jun;44(6):785-795.

61. Garrido-Sanabria ER, Otalora LF, Arshadmansab MF, et al. Impaired expression and function of group II metabotropic glutamate receptors in pilocarpine-treated chronically epileptic rats. Brain Res. 2008;1240:165-176.

62. Ermolinsky B, Pacheco Otalora LF, Arshadmansab MF, et al. Differential changes in mGlu2 and mGlu3 gene expression following pilocarpine-induced status epilepticus: a comparative real-time PCR analysis. Brain Res. 2008;1226:173-180.

63. Dalby NO, Thomsen C. Modulation of seizure activity in mice by metabotropic glutamate receptor ligands. J Pharmacol Exp Ther. 1996;276(2):516-522.

64. Attwell PJ, Singh Kent N, Jane DE, et al. Anticonvulsant and glutamate release-inhibiting properties of the highly potent metabotropic glutamate receptor agonist $\left(2 S, 2^{\prime} R, 3^{\prime} R\right)-2-\left(2^{\prime}, 3^{\prime}-\right.$ dicarboxycyclopropyl)glycine (DCG-IV). Brain Res. 1998 Sep 14;805(1-2):138-143.
65. Miyamoto $M$, Ishida $M$, Shinozaki $H$. Anticonvulsive and neuroprotective actions of a potent agonist (DCG-IV) for group II metabotropic glutamate receptors against intraventricular kainate in the rat. Neuroscience. 1997;77(1):131-140.

66. Caulder EH, Riegle MA, Godwin DW. Activation of group 2 metabotropic glutamate receptors reduces behavioral and electrographic correlates of pilocarpine induced status epilepticus. Epilepsy Res. 2014 Feb;108(2):171-181.

67. Swanson CJ, Bures M, Johnson MP, et al. Metabotropic glutamate receptors as novel targets for anxiety and stress disorders. Nat Rev Drug Discov. 2005 Feb;4(2):131-144.

68. Zhang H, Cilz NI, Yang C, et al. Depression of neuronal excitability and epileptic activities by group II metabotropic glutamate receptors in the medial entorhinal cortex. Hippocampus. 2015 Nov;25 (11):1299-1313.

69. Kłodzińska A, Bijak M, Chojnacka-Wójcik E, et al. Roles of group II metabotropic glutamate receptors in modulation of seizure activity. Naunyn Schmiedebergs Arch Pharmacol. 2000 Mar;361 (3):283-288

70. Yao H, Feng YB, Pang YJ, et al. Inhibitory effect of group II mGluR agonist $2 \mathrm{R}, 4 \mathrm{R}-\mathrm{APDC}$ on cell proliferation in dentate gyrus in rats with epileptic seizure. Eur Rev Med Pharmacol Sci. 2015 Aug;19 (15):2922-2927.

71. Metcalf CS, Klein BD, Smith MD, et al. Efficacy of mGlu(2) -positive allosteric modulators alone and in combination with levetiracetam in the mouse $6 \mathrm{~Hz}$ model of psychomotor seizures. Epilepsia. 2017 Mar;58(3):484-493.

72. Metcalf CS, Klein BD, Smith MD, et al. Potent and selective pharmacodynamic synergy between the metabotropic glutamate receptor subtype 2-positive allosteric modulator JNJ-46356479 and levetiracetam in the mouse 6- $\mathrm{Hz}$ (44-mA) model. Epilepsia. 2018 Mar;59(3):724-735.

- An excellent article showing the pharmcodynamic synergism between mGlu2 receptor PAMs and levetiracetam in animal models of epilepsy.

73. Moldrich RX, Jeffrey M, Talebi A, et al. Anti-epileptic activity of group II metabotropic glutamate receptor agonists (-)-2-oxa-4-aminobicyclo [3.1.0] hexane-4,6-dicarboxylate (LY379268) and (-)-2-thia-4-aminobicyclo [3.1.0]hexane-4,6-dicarboxylate (LY389795). Neuropharmacology. 2001;41(1):8-18.

74. Ngomba RT, Biagioni F, Casciato S, et al. The preferential mGlu2/3 receptor antagonist, LY341495, reduces the frequency of spike-wave discharges in the WAG/Rij rat model of absence epilepsy. Neuropharmacology. 2005;49(Suppl 1):89-103.

75. Mercier MS, Lodge D. Group III metabotropic glutamate receptors: pharmacology, physiology and therapeutic potential. Neurochem Res. 2014 Oct;39(10):1876-1894.

76. Chen J, Larionov S, Pitsch J, et al. Expression analysis of metabotropic glutamate receptors I and III in mouse strains with different susceptibility to experimental temporal lobe epilepsy. Neurosci Lett. 2005 Mar 3;375(3):192-197.

77. Ghauri M, Chapman AG, Meldrum BS. Convulsant and anticonvulsant actions of agonists and antagonists of group III mGluRs. Neuroreport. 1996 Jun 17;7(9):1469-1474.

78. Szczurowska E, Mareš P. Positive allosteric modulator of mGluR4 PHCCC exhibits proconvulsant action in three models of epileptic seizures in immature rats. Physiol Res. 2012;61(6):619-628.

79. Chapman AG, Talebi A, Yip PK, et al. Anticonvulsant activity of a mGlu (4alpha) receptor selective agonist, (1S,3R,4S)-1-aminocyclopentane1,2,4-tricarboxylic acid. Eur J Pharmacol. 2001 Jul 20;424(2):107-113.

80. Sansig G, Bushell TJ, Clarke VR, et al. Increased seizure susceptibility in mice lacking metabotropic glutamate receptor 7. J Neurosci. 2001 Nov 15;21(22):8734-8745.

81. Folbergrová J, Druga R, Haugvicová R, et al. Anticonvulsant and neuroprotective effect of (S)-3,4-dicarboxyphenylglycine against seizures induced in immature rats by homocysteic acid. Neuropharmacology. 2008 Mar;54(4):665-675.

82. Kral T, Erdmann E, Sochivko D, et al. Down-regulation of mGluR8 in pilocarpine epileptic rats. Synapse. 2003 Mar 15;47(4):278-284. 
83. Ngomba RT, Santolini I, Salt TE, et al. Metabotropic glutamate receptors in the thalamocortical network: strategic targets for the treatment of absence epilepsy. Epilepsia. 2011 Jul;52(7):1211-1222.

84. Snead OC 3rd, Banerjee PK, Burnham M, et al. Modulation of absence seizures by the GABA(A) receptor: a critical role for metabotropic glutamate receptor 4 (mGluR4). J Neurosci. 2000 Aug 15;20(16):6218-6224.

85. Ngomba RT, Ferraguti F, Badura A, et al. Positive allosteric modulation of metabotropic glutamate 4 (mGlu4) receptors enhances spontaneous and evoked absence seizures. Neuropharmacology. 2008 Feb;54(2):344-354.

86. Muhle H, von Spiczak S, Gaus V, et al. Role of GRM4 in idiopathic generalized epilepsies analysed by genetic association and sequence analysis. Epilepsy Res. 2010 May;89(2-3):319-326.

87. Parihar R, Mishra R, Singh SK, et al. Association of the GRM4 gene variants with juvenile myoclonic epilepsy in an Indian population. J Genet. 2014 Apr;93(1):193-197.

88. Santos BPD, Marinho CRM, Marques TEBS, et al. Genetic susceptibility in juvenile myoclonic epilepsy: systematic review of genetic association studies. PLoS One. 2017 Jun 21;12(6):e0179629.

89. Bertaso F, Zhang C, Scheschonka A, et al. PICK1 uncoupling from mGluR7a causes absence-like seizures. Nat Neurosci. 2008 Aug; 11(8):940-948.

- An excellent article paving the way to the study of mGlu7 receptors in the control of absence seizures.

90. Zhang CS, Bertaso F, Eulenburg V, et al. Knock-in mice lacking the PDZ-ligand motif of mGluR7a show impaired PKC-dependent autoinhibition of glutamate release, spatial working memory deficits, and increased susceptibility to pentylenetetrazol. J Neurosci. 2008 Aug 20;28(34):8604-8614.

91. Tassin V, Girard B, Chotte A, et al. Phasic and tonic mGlu7 receptor activity modulates the thalamocortical network. Front Neural Circuits. 2016 Apr 25;10:31.

92. Kyuyoung $\mathrm{CL}$, Huguenard JR. Modulation of short-term plasticity in the corticothalamic circuit by group III metabotropic glutamate receptors. J Neurosci. 2014 Jan 8;34(2):675-687.
93. Swedberg MD, Raboisson P. AZD9272 and AZD2066: selective and highly central nervous system penetrant mGluR5 antagonists characterized by their discriminative effects. J Pharmacol Exp Ther. 2014 Aug;350(2):212-222.

94. Rook JM, Xiang Z, Lv X, et al. Biased mGlu5-positive allosteric modulators provide in vivo efficacy without potentiating mGlu5 modulation of NMDAR currents. Neuron. 2015 May 20;86 (4):1029-1040.

95. Russo E, Citraro R, Constanti A, et al. Upholding WAG/Rij rats as a model of absence epileptogenesis: hidden mechanisms and a new theory on seizure development. Neurosci Biobehav Rev. 2016;71:388-408.

96. Childress ES, Wieting JM, Felts AS, et al. Discovery of novel central nervous system penetrant metabotropic glutamate receptor subtype 2 (mGlu(2)) Negative Allosteric Modulators (NAMs) Based on Functionalized Pyrazolo[1,5- a]pyrimidine-5-carboxamide and Thieno[3,2- b]pyridine-5-carboxamide cores. J Med Chem. 2018 Oct 31;62(1).

97. Engers JL, Bollinger KA, Weiner RL, et al. Design and synthesis of N-Aryl Phenoxyethoxy Pyridinones as Highly Selective and CNS Penetrant mGlu(3) NAMs. ACS Med Chem Lett. 2017 Aug 15;8 (9):925-930.

98. Bollinger KA, Felts AS, Brassard CJ, et al. Design and synthesis of mGlu(2) NAMs with improved potency and CNS penetration based on a truncated picolinamide core. ACS Med Chem Lett. 2017 Aug 3;8(9):919-924.

99. Engers JL, Rodriguez AL, Konkol LC, et al. Discovery of a selective and CNS penetrant negative allosteric modulator of metabotropic glutamate receptor subtype 3 with antidepressant and anxiolytic activity in rodents. J Med Chem. 2015 Sep 24;58(18):7485-7500.

100. Kano M, Watanabe T. Type-1 metabotropic glutamate receptor signaling in cerebellar Purkinje cells in health and disease. F1000Res. 2017 Apr 4;6:416.

101. Ngomba RT, van Luijtelaar G. Metabotropic glutamate receptors as drug targets for the treatment of absence epilepsy. Curr Opin Pharmacol. 2018 Feb;38:43-50. 